\title{
Farm level technical efficiency for pulse production in India
}

\author{
Rajni Jain ${ }^{1}$, Sonia Chauhan ${ }^{1}$, S.K. Srivastava ${ }^{1}$, Kingsley I.T. ${ }^{1}$, S.S. Raju ${ }^{2}$, \\ Jaspal Singh ${ }^{1}$ and Amrit Pal Kaur ${ }^{1}$
}

${ }^{1}$ ICAR-National Institute of Agricultural Economics and Policy Research, New Delhi, India ${ }^{2}$ ICAR-Central Marine Fisheries Research Institute, Regional Centre, Visakhapatnam, India

\begin{abstract}
Pulses are complementary to cereals both in production as well as in consumption. During the production process, pulses help in improving sustainability by (i) fixing the atmospheric nitrogen into the soil (ii) consuming less water and (iii) controlling diseases and pests. On consumption front, pulses reduce malnutrition and improve human health being a rich and most viable source of protein for vegetarians and poor people. Realizing the importance of pulses, the government of India announces various schemes and programs from time to time to promote the cultivation of pulses in the country. However, pulse production in India has not achieved the targeted level. The paper analyses the production trend of pulses over the last decade and identifies the gap between the targets and achievements. Plot level data from cost of cultivation scheme across major pulses growing states has been used to estimate technical efficiencies of the pulses using data envelopment analysis. The paper also highlights the yield gap of the pulses across major pulse growing states and suggests suitable measures for improving farm level profitability and sustainability by increasing technical efficiency. The study postulated the hypothesis that technical efficiency of the pulses is low and the yield potential of the pulses are not fully harnessed. The results revealed that increase of technical efficiency by $1 \%$ will reduce the yield gap by $9 \mathrm{~kg}$ per ha and increase total pulse production of the country by 225 thousand tons.
\end{abstract}

Keywords: Pulses, technical efficiency, data envelopment analysis, cost of cultivation

Pulse crops have been an important component of agriculture since ancient times. Pulses are complementary to cereals production as biological nitrogen fixation of pulses contributes at least four

\begin{tabular}{|l|l|}
\hline \multicolumn{2}{|c|}{ Access this article online } \\
\hline Publisher & $\begin{array}{l}\text { Website: } \\
\text { http://www.ndpublisher.in }\end{array}$ \\
\cline { 2 - 2 } & DOI: 10.5958/0976-4666.2016.00068.1 \\
\hline
\end{tabular}

times more nitrogen to the soil throughout the world. On global basis the symbiotic association between legume and Rhizobium reduce about 70 million tonnes (mt) of atmospheric nitrogen to ammonia per annum which amounts to about $40 \%$ of all biologically fixed nitrogen per year (Burns and Hardy, 1975). Pulses play an important role in Indian diet also (Ali and Gupta, 2012). Pulses reduce malnutrition and improve human health as they contain higher protein than any other component of vegetarian diet like cereals and vegetables (Sundaram, 2010).

\section{Address for correspondence}


India is the largest producer, consumer and processor of the pulses in the world (Srivastava et. al., 2010). The position of India in the world market of pulses is rather peculiar (Mruthyunjaya, 1997). Though in quantity term, its position is dominant, yet the country is in short supply of pulses by 2-3 $\mathrm{mt}$ per annum. The domestic production of pulses has been hovering between 13 to $19 \mathrm{mt}$ which is coming from 23 to 25 million hectare area. Notwithstanding, the pulses production in India increased from 13.12 million tonnes $(\mathrm{mt})$ during 200405 to $19.25 \mathrm{mt}$ during 2013-14. However, inspite of increasing pulses production during the recent years, gap between demand and supply is expected to widen in coming years (IIPR, 2013).

If the population continues to grow at the rate of $1.4 \%$ per annum then the demand for pulses is estimated as $39 \mathrm{mt}$ for 1.69 billion population by the year 2050 (IIPR, 2013). Thus, an increase in production of about $0.6 \mathrm{mt}$ per annum will be required to meet the projected demand for pulses. Consequently, both the yield and area under pulses need to be raised to about $1200 \mathrm{~kg}$ per ha and 3-5 million ha respectively. However, as the scope of area expansion under pulses is limited, a paradigm shift in research and technology dissemination is required to increase the pulse production (IIPR, 2013). Inefficiency in crop production is considered as one of the major factors hindering the exploitation of full potential of the innovated technologies (Sekhon et al., 2010). Therefore, it is pertinent to examine the existing level of technical efficiency and estimate the yield which can be increased by improving production efficiency. The study postulated the hypotheses that technical efficiency of the pulses is low and the yield potential of the pulses are not fully harnessed.

\section{Data and Methodology}

The study is based on the unit-level data collected under "Comprehensive Scheme for Cost of Cultivation (CCS) of Principal Crops" of Directorate of Economics and Statistics, Ministry of Agriculture and Farmers Welfare, Government of India for the year 2012-13 for all major pulse growing states. The study covered major pulses viz., red-gram, bengal-gram, lentil, green-gram and black-gram.
Technical efficiency (TE) is defined as the ability to derive maximum output per unit of resource. It is a key to effectively address the challenge of achieving food security in the country (Bakhsh et al., 2006).

Farms having same level of output from lower level of inputs or higher level of output from same level of inputs are considered having better resource use efficiency.

The study compares the technical efficiency of farms in different states and among various size-groups. To enable the comparison of efficiencies of farms in different regions that operate under different technologies the meta-frontier production function is used in literature (Battese et al., 2004). The meta-frontier production function is an envelope of different frontier production functions. Since pulses are cultivated in marginal and rain-fed land with poor agronomy practices, the metafrontier production function with no technical gap ratio is suitable for comparing technical efficiency. That is equal to conducting DEA (Data Envelopment Analysis) crop-wise together for all the states. Thus, technical efficiency of each of the major pulses has been estimated under the assumption of homogeneous production environment in different states.

DEA is a Linear Programming technique for constructing a non-parametric piece wise linear envelop to a set of observed output and input data (Coelli, 1998; Worthington, 1999). Technical efficiency score of each farm is estimated in relation to the farms with minimum input-output ratio. The score of the most efficient farms being one, the score of each farm will lie between zero and one. The data for each crop has been pooled statewise for employing DEA analysis so that the coefficients of each crop can be compared among the states.

Mathematically, let us assume that we have $K$ farmers Decision Making Unit (DMU) using $N$ inputs to produce $M$ outputs. Inputs are denoted by $x_{i k}(\mathrm{j}=1,2, \ldots \ldots, \mathrm{n})$ and the outputs are represented by $y_{i k}(i=1,2, \ldots \ldots . . m)$ for each farmer $k(k=1,2, \ldots \ldots \ldots, K)$. The technical efficiency (TE) of the farmers can be measured as (Coelli, 1998; Worthington, 1999):

$$
T E_{k}=\sum_{i=1}^{m} u_{i} y_{i k} / \sum_{j=1}^{n} v_{j} x_{j k}
$$


where, $\mathrm{Y}_{\mathrm{i} \mathrm{k}}$ is the quantity of the $\mathrm{i}^{\text {th }}$ output produced by the $k^{\text {th }}$ farmer, $x_{j k}$ is the quantity of $j^{\text {th }}$ input used by the $k^{\text {th }}$ farmer, and $u_{i}$ and $v_{j}$ are the output and input weights respectively. For the present analysis, labour use, fertilizer (NPK), insecticide cost, seed rate and irrigation hours were taken as inputs per hectare and yield of respective pulse crop was taken as output. The farmer maximizes the technical efficiency, $\mathrm{TE}_{k^{\prime}}$ subject to,

$$
T E_{k}=\sum_{i=1}^{m} u_{i} y_{i k} / \sum_{j=1}^{n} v_{j} x_{j k} \leq 1
$$

where, $u_{i}$ and $v_{j} \geq 0$

The above equation indicates that the technical efficiency measure of a farmer cannot exceed one, and the input and output weights are positive. The weights are selected in such a way that the farmer maximizes its own technical efficiency which is executed separately. To select optimal weights, technical efficiency of each farmer $\left(\mathrm{TE}_{\mathrm{k}}\right)$ is minimized subject to the following constraints,

$$
\sum_{i=1}^{m} u_{i} y_{i k}-y_{j k}+w \geq 0
$$

where, $\mathrm{k}=1,2 \ldots \ldots \ldots \ldots, \mathrm{k}$

$$
x_{j k}-\sum_{j=1}^{n} u_{j} x_{j k} \geq 0
$$

and $u_{i} \geq 0 ; v_{j} \geq 0$

In the present study the value zero is used for $w$. The zero value of $w$ signifies that the TE estimations in this paper are under the assumption of constant returns to scale. TE value of one implies that the DMU is the best performer located on the production frontier and has no reduction potential. Any value of TE lower than one indicates that the DMU uses inputs inefficiently (Mousavi-Avval et al., 2011).

Based on estimated technical efficiency, yield gap in pulse crops across different states was estimated as follows:

Potential Yield $=$ Existing Yield $*$ (1-Technical Efficiency)

Yield gap $=$ Potential Yield - Existing yield

\section{Results and Discussion}

\section{Pulses scenario in India}

India is the largest producer of the pulses in world but on yield front its rank is very poor. Reasons for low productivity are poor spread of improved varieties and technologies, abrupt climatic changes and vulnerability to pests and diseases (CII, 2010). Table 1 reports the production targets set by the government, domestic supply and demand for pulses in India. By and large the production of pulses has always remained below the government set targets. The gap between production and demand has resulted in shortage of pulses in the country (negative values in Table 1). Therefore to meet the pulses requirement, 2-3 $\mathrm{mt}$ of pulses are imported every year. Moreover, daily per capita availability of pulses has drastically declined from a comfortable position of 60.7 $\mathrm{gm} /$ person/day in 1951 to $31.6 \mathrm{gm} /$ person/day during TE 2010 against ICMR (Indian Council of Medical Research) recommendation of $40 \mathrm{gm} /$ person/ day (Srivastava et al., 2013) which is a serious concern for government, policy makers and researchers.

Table 1: Target, domestic supply and demand for pulses in India (mt)

\begin{tabular}{ccccc}
\hline Year & $\begin{array}{c}\text { Government Production Demand Gap = (Production } \\
\text { Target }\end{array}$ & & & Demand) \\
\hline $2000-01$ & 15.00 & 11.10 & 16.02 & -4.92 \\
$2004-05$ & 15.30 & 13.10 & 17.10 & -4.00 \\
$2008-09$ & 15.50 & 14.60 & 17.51 & -2.91 \\
$2009-10$ & 16.60 & 14.66 & 18.29 & -3.63 \\
$2010-11$ & 16.50 & 18.24 & 19.08 & -0.84 \\
$2011-12$ & 17.00 & 17.09 & 19.91 & -2.82 \\
$2012-13$ & 18.24 & 18.34 & $20-21$ & -1.66 \\
$2013-14$ & 19.00 & 19.27 & $21-22$ & -1.73 \\
$2016-17$ & 20.75 & $18-21$ & 22.00 & -1.0 \\
$2020-21$ & 24.00 & 24.00 & 25.00 & -1.0 \\
\hline
\end{tabular}

Source: 1. Pocket Book of Agricultural Statistics, 2015, Ministry of Agriculture and Farmers Welfare, Government of India

2. IIPR, 2013

The concerted efforts of the government has resulted in increase in the area and production of pulses and 
reduction in pulse imports for some of the years but that could not be sustained in long run (Chauhan and Chauhan, 2011). In order to achieve self-sufficiency in pulse production and reduction in pulse import, it is important to improve pulses productivity. That can be achieved by harnessing the full potential of the Indian farms by improving the existing level of farm level efficiencies. The prevailing farm level efficiency are estimated and explained in next section.

\section{Estimation of resource use efficiencies}

Red-gram, chickpea, lentil, green-gram and black-gram are the major pulses grown in India. State-wise technical efficiencies of these five pulses are presented in Table 2. The table shows that average inefficiency in most of the pulses is more than $50 \%$ except in the case of lentil. The farmers of the country are unable to harness the farm potential fully in most of pulse crops. The average technical efficiency of red-gram cultivation is merely $41 \%$.

Approximately $60 \%$ of the farm potential of red-gram could not be harnessed. Some states particularly Madhya Pradesh and Uttar Pradesh are found to be technically more efficient than the other states. These two states are better off in terms of farm resource use efficiency than national average and have managed to reduce inefficiency below $50 \%$.

In chickpea, technical efficiency in almost each state is less than $40 \%$ except Rajasthan where it is $43 \%$ (Table 2). Average technical efficiency of chickpea is as low as $35 \%$. Rajasthan, Maharashtra and Chhattisgarh are the states which are obtaining more output from the given inputs than other states. As per our estimates, Rajasthan cultivates chickpea most efficiently among all major chick pea growing states.

It is interesting to observe that among all pulse crops country is technically most efficient in cultivation of lentil as its technical efficiency is found to more than $60 \%$ in all major lentil growing states. West Bengal and Uttar Pradesh have technical efficiency as 65\% and 66\% respectively. On the contrary for green-gram, average technical efficiency for the country is nearly $32 \%$. Among states Andhra Pradesh is reported as technically most efficient in green gram cultivation followed by Karnataka and Maharashtra respectively.

Table 2: State-wise technical efficiencies of major pulses of India

\begin{tabular}{cccccc}
\hline States & \multicolumn{2}{c}{ Redgram Chickpea } & Lentil & $\begin{array}{c}\text { Green- } \\
\text { gram }\end{array}$ & $\begin{array}{c}\text { Black- } \\
\text { gram }\end{array}$ \\
\hline $\begin{array}{c}\text { Andhra } \\
\text { Pradesh }\end{array}$ & 0.32 & 0.34 & - & 0.61 & 0.61 \\
Bihar & - & 0.26 & 0.60 & - & - \\
Chhattisgarh & - & 0.36 & - & - & 0.86 \\
Gujarat & 0.38 & - & - & - & - \\
Karnataka & 0.31 & 0.24 & - & 0.49 & - \\
Madhya & 0.57 & 0.33 & 0.62 & - & 0.49 \\
Pradesh & & & & & \\
Maharashtra & 0.40 & 0.39 & - & 0.37 & 0.43 \\
Odisha & 0.34 & - & - & 0.26 & 0.33 \\
Rajasthan & - & 0.43 & - & 0.26 & 0.59 \\
Tamil Nadu & - & - & - & 0.33 & 0.39 \\
Uttar & 0.56 & 0.34 & 0.66 & - & 0.47 \\
Pradesh & & & & & - \\
West Bengal & - & - & 0.65 & - & - \\
All India & 0.41 & 0.35 & 0.62 & 0.32 & 0.45 \\
\hline
\end{tabular}

Source: Computed by the Authors

*It includes the average of sample data from selected states.

Chhattisgarh is observed as most efficient in cultivating black gram with technical efficiency as high as $86 \%$. Andhra Pradesh, Rajasthan and Madhya Pradesh are the other states which have ability to produce more output using the given inputs as compared to the national average.

To understand the distribution of inefficient farmers in pulse growing states, an attempt has been made to compute percentage of the farmers below the national average (Table 3). It is shocking to observe that around $60 \%$ of the farmers in the country are technically lagging behind than the national average of technical efficiency for each pulse crop. The condition of the farmers of the state like Odisha is critical as about $90 \%$ farmers have been found technically inefficient than the national average. The farmers cultivating red-gram, green-gram and black-gram were found to be technically most 
inefficient in production of these crops. It is interesting to observe that pulses growers in one pulse are highly inefficient whereas in other pulses they are efficient. For example in case of red gram, Andhra Pradesh witnesses $75 \%$ farmers having lesser technical efficiency than the national average whereas in black-gram it is just $19 \%$. The reason could be that natural resources and climatic conditions of particular state are more suitable for cultivation of a specific pulse crop. Thus, the crop specific and region specific cultivation plans are required to harness the full farm potential. In case of chickpea, more than $82 \%$ farmers of Bihar are having technical efficiency less than national average of $35 \%$. As in Table 2, the situation is better in case of lentil. In case of green gram, in Odisha nearly $84 \%$ farmers are less than national average technical efficiency of $32 \%$. The situation is worst for black-gram in Odisha where 89\% farmers are below national average of TE i.e. $45 \%$.

Table 3: Farmer below National Average in TE-2011 (\%)

\begin{tabular}{|c|c|c|c|c|c|}
\hline State & Redgram & Chickpea & Lentil & $\begin{array}{c}\text { Green- } \\
\text { gram }\end{array}$ & $\begin{array}{c}\text { Black- } \\
\text { gram }\end{array}$ \\
\hline $\begin{array}{l}\text { Andhra } \\
\text { Pradesh }\end{array}$ & 75.0 & 61.3 & & 21.7 & 18.8 \\
\hline Bihar & & 82.3 & 66.5 & & \\
\hline Chhattisgarh & & 50.0 & & & \\
\hline Gujarat & 67.1 & & & & \\
\hline Karnataka & 73.1 & 74.6 & & 29.2 & \\
\hline $\begin{array}{l}\text { Madhya } \\
\text { Pradesh }\end{array}$ & 35.0 & 57.2 & 55.0 & & 42.0 \\
\hline Maharashtra & 60.2 & 47.2 & & 54.9 & 61.9 \\
\hline Odisha & 76.5 & & & 83.9 & 88.5 \\
\hline Rajasthan & & 32.7 & & 65.3 & 35.1 \\
\hline Tamil Nadu & & & & 52.5 & 72.1 \\
\hline $\begin{array}{c}\text { Uttar } \\
\text { Pradesh }\end{array}$ & 22.8 & 65.6 & 41.9 & & 59.5 \\
\hline West Bengal & & & 47.1 & & \\
\hline All India & 57.9 & 55.4 & 58.1 & 65.6 & 59.6 \\
\hline
\end{tabular}

Source: Computed by authors

*It includes the average of sample data from selected states.

To study the effect of farm-size on technical efficiency, the farm households were classified into five categories according to their farm sizes, viz. marginal, small, semi-medium, medium and large (Table 4). Technical efficiency of each crop was estimated for all classes and the results reveal that overall situation is not different across farm size categories. Farm sizes do not play significant role in harnessing the potential of the pulse farms as the difference of technical efficiency between any two farm-size category is not significant. It may be inferred that none of the farm-size groups are giving importance to the cultivation of pulses because pulses are considered as non-lucrative. Interestingly, the table shows that the marginal farms are found to be better than semi-medium and medium farms for some pulses. This could be because they use very less amount of inputs or most of the operations are done by family members themselves and remain unreported. The significance level of differences across farm size categories were studied with help of Analysis of Variance (ANOVA) as presented in Fig. 1.

Table 4: Farm-size wise technical efficiency of major pulses

\begin{tabular}{cccccc}
\hline Farm Size & $\begin{array}{c}\text { Red- } \\
\text { gram }\end{array}$ & $\begin{array}{c}\text { Bengal- } \\
\text { gram }\end{array}$ & $\begin{array}{c}\text { Lentil } \\
\text { Green- }\end{array}$ & $\begin{array}{c}\text { Black- } \\
\text { gram }\end{array}$ \\
\hline $\begin{array}{c}\text { Marginal } \\
\text { (less than 1ha) }\end{array}$ & 0.39 & 0.35 & 0.6 & 0.34 & 0.42 \\
$\quad \begin{array}{c}\text { Small } \\
\text { (1-2 ha) }\end{array}$ & 0.43 & 0.34 & 0.59 & 0.29 & 0.42 \\
$\quad \begin{array}{c}\text { Medium } \\
\text { (2-4 ha) }\end{array}$ & 0.41 & 0.34 & 0.62 & 0.32 & 0.49 \\
$\begin{array}{c}\text { Semi-medium } \\
\text { (4-6 ha) }\end{array}$ & 0.41 & 0.35 & 0.62 & 0.33 & 0.46 \\
$\begin{array}{c}\text { Large } \\
\text { (greater than 6 ha) }\end{array}$ & 0.40 & 0.37 & 0.71 & 0.34 & 0.44 \\
\hline
\end{tabular}

Source: Computed by the authors

Fig. 1 highlight state-wise and farm-size wise comparison of technical efficiency for each crop. Interstate comparison of technical efficiency are computed for these five pulse crops and found to be highly significant for red-gram, bengal-gram, black-gram, green-gram except lentil crop. $\mathrm{F}$ values in case of state comparisons shows that inter-state variation of the pulses technical efficiencies are significant except in case of lentil. Smaller value of $\mathrm{F}$ for comparison of technical efficiency among farm-size categories reveals that there are not significant 
\ Jain et al.

INTER-STATE-WISE

FARM HOLDING SIZE-WISE

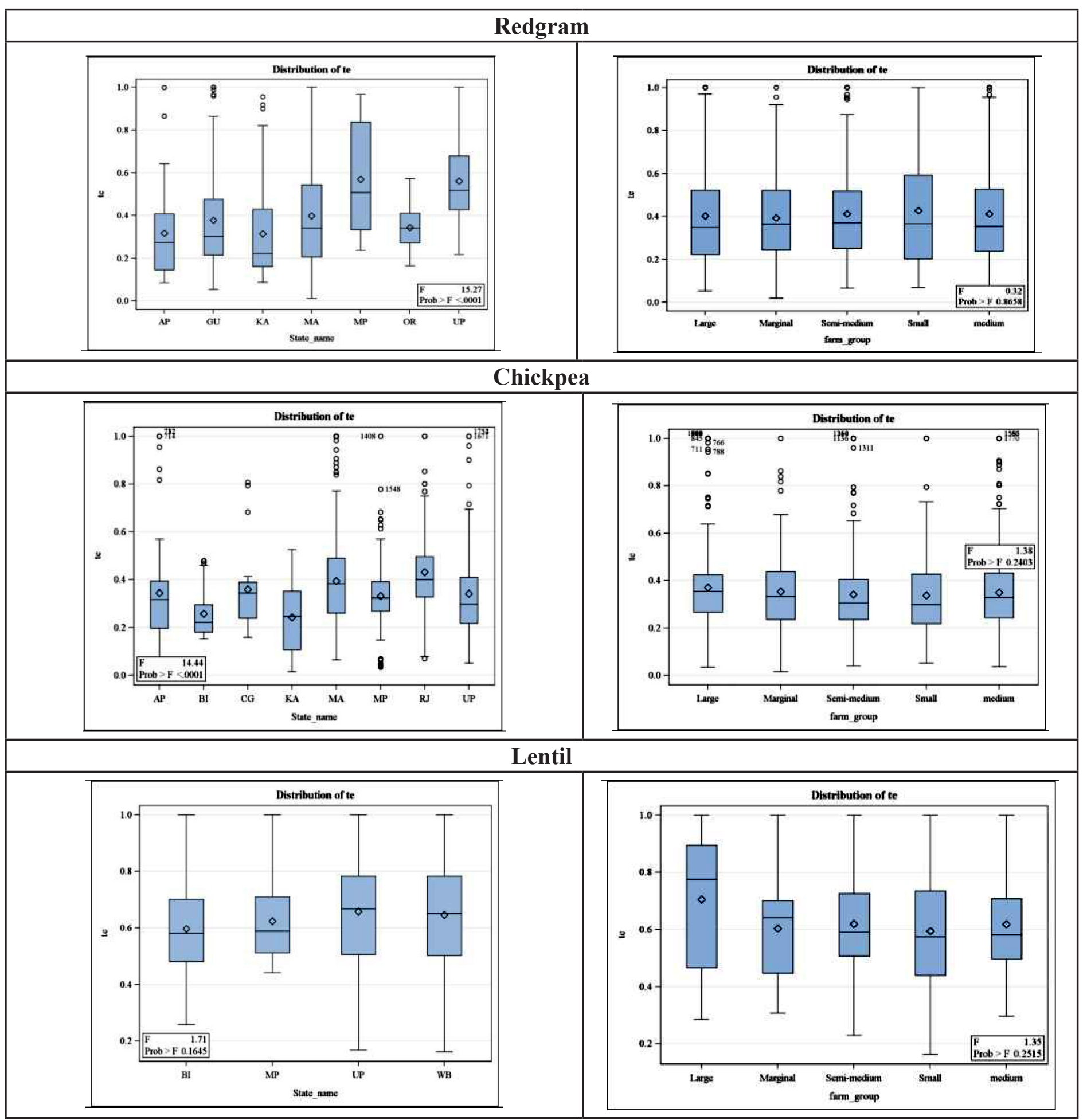

(Cont...) 


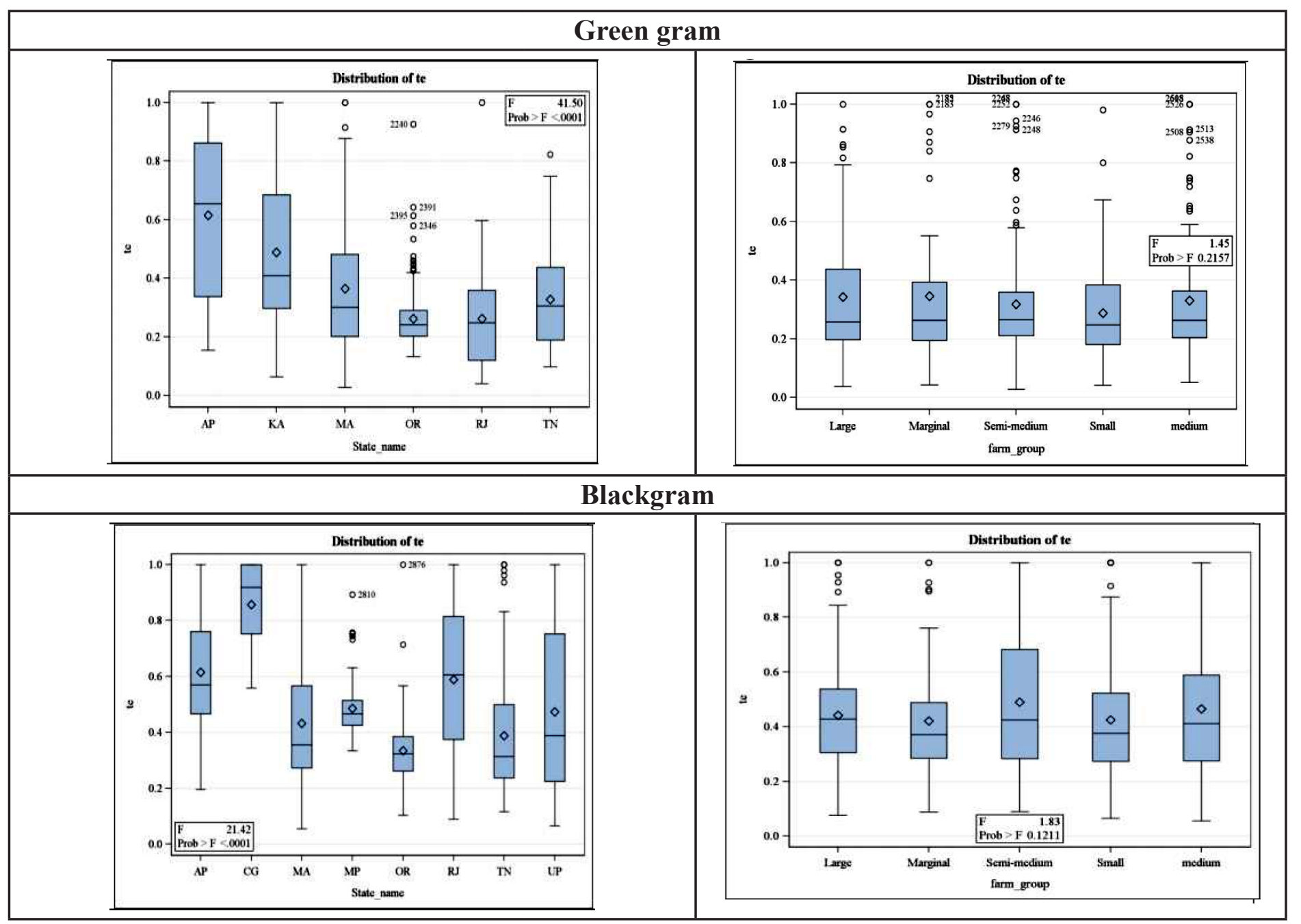

Fig. 1: Comparison of technical Efficiency of pulses

differences across farm size categories. The Jenkins box in each figure represents distribution of farm technical efficiency between first and third quartile. The diamond in the middle of each box in Fig. 1 represents the mean of TE in the corresponding state. The horizontal line inside the box represents median TE. We observe that in each pulse crop, most of the states have more than $50 \%$ farms having TE less than the state average. This suggests that there is a lot of scope to improve the technical efficiency of the farms with extensive dissemination of technology and favorable government policies.

Joshi and Saxena (2002) observed the need to tap yield potential for improving pulse production in the country. However, the yield gap estimates were based on potential yield observed from demonstration experiments. Thus, the used potential yield was far from realistic situation. In this paper, the potential yield has been estimated using farm level data as explained in the methodology. The yield gap between existing yield and potential yield of all pulse crops in major pulse growing states have been estimated and presented in Table 5. It can be inferred from Table 5 that there exist a yield gap to the tune of $770 \mathrm{~kg} / \mathrm{ha}$ of red-gram, 735 $\mathrm{kg} / \mathrm{ha}$ of chickpea, $340 \mathrm{~kg} / \mathrm{ha}$ of lentil, $300 \mathrm{~kg} / \mathrm{ha}$ of green-gram and $323 \mathrm{~kg} / \mathrm{ha}$ of black-gram. Further, it is observed that the yield levels in major pulse growing states can be improved by harnessing the potential yield of the pulses. We estimated that if the technical 
efficiency is increased by one per cent with improved and recommended crop practices then nearly $9 \mathrm{~kg} / \mathrm{ha}$ of pulses can be additionally produced.

Table 5: Yield gap of selected pulse crops in major pulse growing states of India (Kg/ha)

\begin{tabular}{|c|c|c|c|c|c|}
\hline State & Red gram & $\begin{array}{c}\text { Bengal } \\
\text { gram }\end{array}$ & Lentil & $\begin{array}{l}\text { Green } \\
\text { gram }\end{array}$ & $\begin{array}{l}\text { Black } \\
\text { gram }\end{array}$ \\
\hline $\begin{array}{l}\text { Andhra } \\
\text { Pradesh }\end{array}$ & 460 & 760 & - & 229 & 339 \\
\hline Bihar & - & 512 & 308 & - & - \\
\hline Chhattisgarh & - & 662 & - & - & 130 \\
\hline Gujarat & 536 & - & - & - & - \\
\hline Karnataka & 655 & 493 & - & 351 & - \\
\hline $\begin{array}{l}\text { Madhya } \\
\text { Pradesh }\end{array}$ & 443 & 825 & 380 & - & 432 \\
\hline Maharashtra & 1178 & 749 & - & 387 & 300 \\
\hline Odisha & 258 & - & - & 257 & 250 \\
\hline Rajasthan & - & 666 & - & 275 & 341 \\
\hline Tamil Nadu & - & & - & 326 & 367 \\
\hline Uttar Pradesh & 411 & 697 & 372 & - & 254 \\
\hline West Bengal & - & & 360 & - & - \\
\hline All India & 770 & 735 & 337 & 299 & 323 \\
\hline
\end{tabular}

Source: Computed by Authors

*It includes the average of sample data from selected states.

Thus total production will increase by 225 thousand tons. It will improve the per capita availability of pulses and also reduce the import bill.

\section{Conclusion}

Pulses are the main components of a diet in our country as majority of the people are vegetarian. The demand for the pulse will be more with the ever growing population in India. It will be difficult to fill the gap between demand and supply of pulses in future. To ensure selfsufficiency and reduce the dependence on import, it is necessary to improve the resource use efficiency of the pulses. About $60 \%$ pulse growers are reported to be inefficient than the national average efficiency. State wise estimation of technical efficiencies of major pulses have indicated that there are significant differences in technical efficiency of each pulse crop among states. Madhya Pradesh, Rajasthan, Uttar Pradesh, Andhra Pradesh and Chhattisgarh are observed to be leading in redgram, bengal gram, lentil, greengram and blackgram respectively in term of technical efficiency. From insignificant differences in technical efficiency across farm size categories, it can be inferred that pulses are less preferable by farmers. There are huge yield gaps for different pulses which can be eliminated in most of the states by increasing the technical efficiency by $45 \%$. For improving technical efficiency, the success model with improved techniques, better credit and infrastructural facilities should be adopted. Investment in R\&D on pulses, improved and pest resistant varieties of seeds and reduction in post-harvest losses of pulses may also help farmers to improve the pulse production and their profitability. Productivity enhancement through the optimum use of inputs is required for sustainable agricultural growth. Further region specific crop plans should be developed with due importance to pulse cultivation. There is a need for pulse revolution to ensure adequate pulse supply and reduce dependence on imports.

\section{Acknowledgements}

The paper is drawn from the ongoing network project on "Regional Crop Planning for Improving Resource Use Efficiency and Sustainability" funded by Indian Council of Agricultural Research (ICAR). The authors duly acknowledge ICAR for providing funds for the project which facilitated conduct of the study.

\section{References}

Ali Masood and Sanjeev Gupta 2012. “Carrying capacity of Indian agriculture: pulse crops", Current Science, 102(6).

Bakhsh, K., Ahmad, B. and Hassan, S. 2006. "Food security through increasing technical efficiency", Asian Journal of Plant Sciences 5(6): 970-976.

Battese, G.E., Rao, D.S.P. and O’Donnell, C.J. 2004. “A Metafrontier Production Function for the estimation of Technical Efficiencies and Technology Gaps for Firms Operating under Different Technologies" Journal of Productivity Analysis 21: 91103. 
Burns and Hardy 1975. "Nitrogen fixation in bacteria and higher plants", Molecular Biology Biochemistry and Biophysics, 21: 1-189.

Chauhan, Sonia and Mangal Singh Chauhan 2011. "Are we moving towards self-sufficiency in pulses?", Agriculture Today, August issue, 2011.

CII, 2010. Overcoming the pulse crisis, Report by Confederation of Indian Industry (CII), New Delhi.

Coelli, T. 1998. A Muti-stage methodology for solution of orientated DEA Models, Operation Research Letters, 23(3-5): 143-149.

IIPR 2013. Vision 2050, ICAR-Indian Institute of Pulses Research, Kanpur.

Joshi, P.K. and Raka Saxena, 2002. "A profile of pulses production in India: Facts, trends and opportunities", Indian Journal of Agricultural Economics, 57(3): 326- 339.

Mousavi-Avval S.H., Rafiee, S., Jafari, A. and Mohammandi, A. 2011. Optimization of energy consumption for soyabean production using Data Envelopment analysis (DEA), Applied Energy. 35: 2156-2164.
Mruthyunjaya 1997. Pulses in India: An Explorative Assessment, Palawija News, The CGPRT Centre New letter.

Pocket Book of Agricultural Statistics 2015. Ministry of Agriculture and Farmers Welfare, Government of India.

Sekhon M.K., Amrit Kaur Mahal, Manjeet Kaur and Sidhu, M.S. 2010. "Technical efficiency in crop production: A region-wise analysis", Agricultural Economics Research Review, 23: 367-374.

Srivastava S.C., Singh, B.K., Sudeep S Tomar and Yadava, H.S. 2013. "Growth pattern of major pulses in eastern Uttar Pradesh" A International Journal of Farm Sciences 3(2): 1-9.

Srivastava S.K., Sivaramane, N. and Mathur, V.C. 2010. “Diagnosis of Pulses Performance in India", Agricultural Economics research Review, 23: 137-148.

Sundaram, Satya 2010. "India Needs A Pulses Revolution", Market Survey, December 2010.

Worthington, A.C. 1999. Measuring Technical efficiency in Australian Credit Unions, Manchester School 67(2): 231-248. 
